\title{
4. Constitutional preconditions for the Finnish basic income experiment
}

Anna-Kaisa Tuovinen

\section{LEGISLATION ENABLING THE EXPERIMENT}

The Finnish basic income experiment was planned and conducted as a mandatory experiment to avoid selection biases and obtain statistically generalisable and reliable results (HE 215/2016 vp). It appears to have been the very first basic income experiment in the world based on mandatory participation and a randomised nationwide sample (2000 persons). An experiment of this kind could not have been implemented without amendments to the social security legislation. Therefore, this chapter examines, albeit rather briefly, the constitutional preconditions for the legislation governing the Finnish basic income experiment.

The rule of law is a fundamental principle of democratic society. The Constitution of Finland (731/1999) requires, among other things, that ' $[\mathrm{t}] \mathrm{he}$ exercise of public powers shall be based on an Act. In all public activity, the law shall be strictly followed' (Section 2.3) and that 'the principles governing the rights and obligations of private individuals and the other matters that under this Constitution are of a legislative nature shall be governed by Acts' (Section 80.1). Owing to these constitutional provisions, individuals cannot be compelled to participate in an experiment in the absence of relevant legislation. Hence, participation in the basic income experiment was made mandatory by law for those who were selected as part of the treatment group via random sampling. This group received the basic income benefit during the course of the experiment in 2017-18 (henceforth, the treatment group).

In addition, the right to social security is not only a human right, but also a fundamental right guaranteed under the Constitution of Finland: '[e]veryone shall be guaranteed by an Act the right to basic subsistence in the event of unemployment, illness, and disability and during old age as well as at the birth of a child or the loss of a provider' (Section 19.2).

The treatment group comprised 2000 persons who were recipients of the basic unemployment allowance or labour market subsidy in November 2016. 
As the right to unemployment benefits is a fundamental right that is guaranteed by law (Unemployment Security Act, 1290/2002), replacing the normal unemployment benefits with basic income required legislation enacted by the Parliament. The outcome was the Act on the Basic Income Experiment (1528/2016) - a piece of legislation enabling the experiment.

\section{ASSESSING EXPERIMENTATION LEGISLATION IN FINLAND}

The function of the Constitution is not only to enable the exercise of public powers but also to set the necessary limitations for it. In Finland, the Constitutional Law Committee of the Parliament is obliged to issue statements on the constitutionality of legislative proposals and their compliance with international human rights treaties (Section 74 of the Constitution; see also Tuori, 2011). ${ }^{1}$ When it comes to the constitutionality of experimentation legislation, the Constitutional Law Committee has evaluated several government bills concerning different societal experimentation projects in recent decades.

It is important to note that societal experiments often require deviation from the principle of equal treatment. However, the Constitutional Law Committee has ruled that the principle of equality does not constitute an impediment to experimentation legislation and that, in an experiment, people may be treated differently from others, within certain limits. During past decades, the Constitutional Law Committee has established the criteria for legislation regulating a societal experiment. (Rautiainen, 2019; Tuovinen, 2017.) Based on the Committee's praxis, the Ministry of Justice issued a 'guide for drafters of legislation enabling experimentation projects in society' in late 2018 (Ministry of Justice, 2020). In accordance with these guidelines, the following criteria must be met by an experimentation legislation (Ministry of Justice, 2020; Rautiainen, 2019; Tuovinen, 2017):

1. Acceptable objective: The objective of an experiment is to obtain evidence-based information for future decision-making. It is assessed especially in light of the fundamental rights system. An experiment must not violate the fundamental rights of any individual; otherwise, the objective of the experiment would be deemed unacceptable. Although the principle of equality is a fundamental right, deviating from it may be possible if the experiment has an acceptable objective.

2. Legislative requirements: In terms of the regulation of fundamental rights and deviation from other legislation during an experiment, provisions regulating an experiment must be enacted by the Parliament. This means that detailed criteria for selecting participants and/or the area where the 
experiment will be conducted (or criteria for determining the area) as well as the scope of the experiment must be based on an act.

3. Proportionality principle: The experimentation legislation must be proportionate to its objective, and only necessary deviations from other legislation are acceptable. An experiment is necessary when the information obtained by the experiment cannot be achieved when applying other less-invasive means. No one should obtain an undue advantage from an experiment. That is, the proportionality criterion is not fulfilled if there are unreasonable differences between the treatment group and those not participating in the experiment.

4. Non-discrimination principle: The experimentation legislation must be non-discriminatory, for instance, in relation to the criteria for selecting participants. However, differences in treatment based on person-related causes (e.g. age) may be justified when there is an acceptable reason, so long as it is not arbitrary.

5. Temporary validity: The experimentation legislation must be temporary. The act may be in effect only for a limited, rather short period of time that is necessary for obtaining reliable results from the experiment.

6. Evaluating the results: The examination and analysis of the results of an experiment must be accurately planned and organised.

\section{THE BASIC INCOME EXPERIMENT IN LIGHT OF THE CONSTITUTIONALITY REVIEW}

In its statement concerning the government bill on the basic income experiment, the Constitutional Law Committee focused on three key dimensions: equality and proportionality, regulation by laws, and clarity of regulation. In addition, the Committee clearly pointed out that in an experiment based on mandatory participation, it is prohibited to reduce the level of social security benefits for the participants (PeVL 51/2016 vp: 5).

\section{Equality and Proportionality}

The idea of controlled experiments is that persons subjected to an experiment are treated differently from others in order to measure the effects of an intervention. Therefore, the target population must be divided into at least two groups: a treatment group and a control group. The basic income experiment placed those in the treatment group in a different position from persons in the control group as well as people outside of the experiment. For this reason, the government bill on the basic income experiment had to be assessed in light of the equality provision of the Constitution (PeVL 51/2016 vp: 2). 
The Constitution of Finland states that '[e]veryone is equal before the law. No one shall, without an acceptable reason, be treated differently from other persons on the ground of sex, age, origin, language, religion, conviction, opinion, health, disability or other reason that concerns his or her person' (Section 6, subsections 1-2). The list in this provision is the core of the non-discrimination principle, but it is not exhaustive. This means that, without an acceptable reason, it is prohibited to treat persons differently based on any other person-related reason such as wealth, family relations, pregnancy, sexual orientation, or residence. (HE 309/1993 vp: 43-4.) The provisions of equal treatment and non-discrimination limit the discretion of the legislator, but the latter more than the former (Rautiainen, 2019: 205).

In line with the government bill, the Constitutional Law Committee held that the random sampling method provides an equal opportunity for each person in the target population to enter the treatment group. This means that in random sampling, there is no different treatment based on person-related reasons; otherwise, it would not be random. Hence, only the general equality provision of the Constitution was applicable in this regard. The Committee held that the experiment complies with Section 6.1 of the Constitution because the objective of the experiment - to study the effects of basic income in society - was acceptable. (PeVL 51/2016 vp: 3.)

However, the bill on the basic income experiment included some person-related limitations in terms of defining the target population based on age and unemployment status. The Constitutional Law Committee held that, taking into consideration the objectives of the experiment, there were acceptable reasons for the differing treatment (PeVL 51/2016 vp: 3). That is, the Constitutional Law Committee accepted that the societal objectives of the basic income experiment were acceptable in light of the fundamental rights system. Regarding other fundamental rights, the basic income experiment was especially aimed at simultaneously securing the right to work (Section 18) and the right to social security (Section 19).

In addition, the principle of proportionality had to be taken into consideration in the assessment of the constitutionality of the experiment. In an experimentation, the principle of proportionality requires that '[d]ifferences in the treatment of those who do and those who do not participate in a given experimentation project must not be unreasonable' (Ministry of Justice, 2020). In other words, experimentation must be necessary and proportionate to its objective, and people should not be put in unreasonably different positions; only reasonable differences are acceptable. When assessing the level of the basic income in the experiment (that is, its cumulative effect), the Constitutional Law Committee noted that persons in the treatment group were in significantly better positions than others. However, the Committee held that the experiment fulfilled the proportionality requirement because the 
experiment was temporary and the objective of the experiment was acceptable in light of the fundamental rights system. (PeVL 51/2016 vp: 3-4.)

\section{Regulation by Law and Clarity of Regulation}

In the government bill, it was proposed that 2000 participants would be selected by random sampling (HE 215/2016 vp: 7). The Constitutional Law Committee noted that the treatment group could not be defined solely by the (random sampling) software code; ${ }^{2}$ the legislative requirements stipulate that the criteria for selecting the participants in an experiment must be provided for by law. In addition, the Committee held that the software code must be made public before completing the selection. (PeVL 51/2016 vp: 5.) These remarks were added to the Basic Income Experiment Act (Section 5) by the Social Affairs and Health Committee of the Parliament (StVM 42/2016 vp; Rautiainen, 2019: 207). Thus, in accordance with Section 5 of that Act, the random sampling had to be conducted in such a way that it provided an equal opportunity for each person in the target population to enter the treatment group.

One of the justifications for the basic income experiment was that the current social security legislation can be considered very complex from the perspective of the beneficiary. Therefore, the beneficiary is not always able to assess, for example, the effect of small earnings on certain benefits. (PeVL 51/2016 vp:5; HE 215/2016 vp: 5.) The Constitutional Law Committee emphasised that special attention should be paid to clear and precise regulation, especially in the context of fundamental rights regulation. In its previous statements, the Constitutional Law Committee required that persons concerned should be able to apply the provisions affecting their daily lives and livelihoods without difficulty. (PeVL 51/2016 vp: 5.) This aspect was of significant relevance in the basic income experiment, and the Social Affairs and Health Committee of the Parliament also highlighted this aspect in its own report. It stated that informing the treatment group about the experiment and its effects on the beneficiary's rights and duties was of utmost importance (StVM 42/2016 vp: 7).

\section{Prohibition against Reducing the Social Security Benefit Levels of the Participants}

The government bill on the basic income experiment was based on the idea that the level of benefit(s) for participants in the basic income experiment should not be lower than that for people outside the experiment (HE 215/2016 vp: 10). In its statement, the Constitutional Law Committee emphasised that the basic income experiment must not reduce the current social security benefits of persons selected for the treatment group (PeVL 51/2016 vp: 5). The Committee ruled that the experiment was acceptable when the individuals involved in the 
experiment were entitled to a benefit level that was at least commensurate with normal benefits (PeVL 51/2016 vp: 3). In other words, in an experiment based on mandatory participation, there is a prohibition against reducing the social security benefits or legal protections of participants. It is important to take this principle into account when assessing the acceptability of an experiment. The Committee was of the opinion that this principle should be clearly laid down in the Act on the Basic Income Experiment (PeVL 51/2016 vp: 5).

However, the Act was passed in the Parliament without this kind of explicit provision. This was because the Social Affairs and Health Committee of the Parliament noted that when coordinating basic income with other social security benefits, the beneficiary of basic income should never receive less income than he/she would get without basic income (i.e. compared with receiving the normal unemployment benefit). Therefore, the Social Affairs and Health Committee held that it was not necessary to enact this separately. (StVM 42/2016 vp: 5.) That is, for those who previously received unemployment benefits with, for instance, a child increase (supplement), it was necessary to apply separately for the child increase in order to maintain the same benefit level. Nonetheless, the principle highlighted by the Constitutional Law Committee materialised de jure, in one way or another. The question of whether it materialised de facto is an empirical one. In the following chapters, the empirical results of the Finnish basic income experiment are described and analysed.

\section{NOTES}

1. A short introduction to the Committees of the Parliament and how they work is available at https://www.eduskunta.fi/EN/valiokunnat/Pages/default.aspx (accessed 28 December 2020).

2. The software code refers to the sampling algorithm used to conduct the randomisation in December 2016, i.e. random selection of the treatment group from the target population. The sampling algorithm is available in Finnish at https://www .kela.fi/web/en/random-sample-algorithm-used-in-the-basic-income-experiment (accessed 28 December 2020).

\section{REFERENCES}

Act on The Basic Income Experiment (1528/2016), Available in Finnish at https:// finlex.fi/fi/laki/alkup/2016/20161528 (accessed 28 December 2020).

The Constitution of Finland (731/1999), Unofficial translation in English available at https://finlex.fi/fi/laki/kaannokset/1999/en19990731.pdf (accessed 28 December 2020).

HE 309/1993 vp. The government bill on amending the fundamental rights provisions of the constitutions (available in Finnish at https://www.eduskunta.fi/FI/vaski/ HallituksenEsitys/Documents/he_309+1993.pdf) (accessed 28 December 2020). 
HE 215/2016 vp. The government bill on the Basic Income Experiment Act (available in Finnish at https://www.eduskunta.fi/FI/vaski/HallituksenEsitys/Documents/HE 215+2016.pdf) (accessed 28 December 2020).

Ministry of Justice (2020), 'Guide for drafters of legislation enabling experimentation projects in society', available in English at http://kokeiluohje.finlex.fi/en/ (accessed 28 December 2020).

PeVL 51/2016 vp. The Constitutional Law Committee Statement - HE 215/2016 vp, available in Finnish at https://www.eduskunta.fi/FI/vaski/Lausunto/Documents/ PeVL_51+2016.pdf (accessed 28 December 2020).

Rautiainen, P. (2019), 'Kokeilulainsäädäntö ja sen perustuslailliset reunaehdot' [Experimental legislation and its constitutional constraints], Lakimies, 2, 192-220.

StVM 42/2016 vp. The Social Affairs and Health Committee Report - HE 215/2016 vp, available in Finnish at https://www.eduskunta.fi/FI/vaski/Mietinto/Documents/ StVM 42+2016.pdf (accessed 28 December 2020).

Tuori, K. (2011), 'Judicial constitutional review as a last resort', in Campbell, T., Ewing, K.D. and Tomkins, A. (eds), The Legal Protection of Human Rights: Sceptical Essays, Oxford: Oxford University Press, pp. 365-91.

Tuovinen, A-K. (2017), Perustuslainmukainen perustulokokeilu. Perustulokokeilun arviointia perustuslain ja kansainvälisten ihmisoikeussopimusten valossa [The Constitutional Framework for the Basic Income Experiment. Assessing the Basic Income Experiment in Light of the Constitution and International Human Rights Treaties], Helsinki: Kelan tutkimus, Työpapereita 114/2017.

Unemployment Security Act (1290/2002), Available in Finnish at https://finlex.fi/fi/ laki/ajantasa/2002/20021290 (accessed 28 December 2020). 